Boise State University

ScholarWorks

Marketing and Finance Faculty Publications and

Presentations

Department of Marketing and Finance

$1-1-2016$

Perceived and Realized Risk Tolerance: Changes During the 2008 Financial Crisis

Diane K. Schooley

Boise State University

Debra Drecnik Worden

George Fox University 


\title{
Perceived and Realized Risk Tolerance: Changes During the 2008 Financial Crisis
}

\author{
Diane K. Schooleya and Debra Drecnik Worden ${ }^{b}$
}

Using the 2007-2009 Survey of Consumer Finances panel data, this study examined changes in perceived and realized risk tolerance after the financial crisis. Households who perceived less risk tolerance were more likely to have reduced their portfolio risk and vice versa. Furthermore, households whose wealth decreased were more likely to perceive less risk tolerance and vice versa. Regression analysis revealed that change in risk tolerance as measured by the change in financial portfolio risk is related to perceived risk tolerance, education, life cycle stage, and employment status. Single households, or those households whose head is less educated, or self-employed or unemployed, may need financial advice to prevent them from reducing their portfolio risk in reaction to a financial crisis.

Keywords: financial crisis, risk tolerance, portfolio composition, behavioral finance

$\mathrm{M}$ any speculate that the recent financial crisis has influenced households to become less tolerant of financial risk, that is, more averse to the variability in returns on investments. Between 2007 and 2009, many households observed substantial declines in the values of their stock portfolio and housing assets. Risk tolerance is modeled, theoretically, to be a function of wealth; these changes in wealth may have been met with changes in risk tolerance. Lower risk tolerance, and thus less portfolio risk, is especially concerning after a downturn. If investors decrease the risk of their portfolios (hold less stock) in reaction to a decline in the stock market, they may be selling stock when the market is relatively low, decreasing their actual wealth, and leading them to miss out on gains as the market recovers.

Financial advisors make recommendations that can influence the financial risk borne by their clients. According to Finke and Huston (2003), willingness to take financial risk is associated with a significantly higher net worth and is a strong predictor of higher net worth for those older than 65 years. Thus, understanding a client's risk tolerance is an important responsibility for financial advisors. If indeed individuals become temporarily more risk averse during economic downturns, advisors may need to provide interventional education to ensure that they do not overreact. Otherwise, they may respond by reducing the risk of their portfolios and foregoing potential wealth accumulation.

Much research has been devoted to identifying factors that impact financial risk tolerance. However, more insight into the changes in risk tolerance that resulted from the 2008 financial crisis will help financial advisors to better counsel their clients. The Survey of Consumer Finances (SCF) interviewed the same sample of households before and after the crisis. The responses provide a unique opportunity to examine how perceived risk tolerance and portfolio risk changed for the sample over this time period.

This article examines changes in household risk tolerance, both perceived and measured by investment behavior preceding the 2008 financial crisis and at its end. After a literature review and data and sample descriptions, univariate analysis considers changes in portfolio risk across changes in perceived risk tolerance. Because these changes could depend on how the financial crisis impacted household wealth, the analysis distinguishes between households who experienced a decrease in wealth during the financial crisis and those who experienced an increase in wealth. Multivariate analysis then explores the factors that explain changes

\footnotetext{
${ }^{a}$ Associate Dean and Professor of Finance, College of Business and Economics, Boise State University, Boise, ID 83725. E-mail: dschoole@boisestate.edu ${ }^{b}$ Professor of Business and Economics, College of Business, George Fox University, 414 N. Meridian Street, 6263, Newberg, OR 97132.

E-mail: dworden@georgefox.edu
} 
in portfolio risk between 2007 and 2009. Finally, results and a discussion of the implications are provided. This study extends the literature by identifying characteristics of those who are most likely to reduce their portfolio risk in reaction to a downturn in financial markets.

\section{Literature Review on Risk Tolerance Insights From Behavioral Finance}

Classic theory (Arrow, 1965) proposed that relative risk aversion (RRA) is a function of wealth. Depending on assumptions about the form of an individual's utility function, RRA may be increasing, constant, or decreasing with respect to wealth. Such conventional theory assumes that individuals are rational wealth maximizers. However, individuals do not always behave according to rational economic model assumptions.

The relatively new field of behavioral finance combines psychology with finance to explain why actual behavior may deviate from that of rational economic agents and can be influenced by emotion. Key concepts identified include availability bias and overreaction. The availability heuristic, introduced by Tversky and Kahneman (1973) is the notion that people tend to weight more heavily the information and events that come to mind more easily. Generally, that leads to decisions that are based on the latest news or dramatic and unexpected events. De Bondt and Thaler (1985) found that investors overreact to new information. In their study, investors overreacted to bad news, driving stock prices down disproportionately, and overreacted to good news, moving stock prices in the opposite direction. Eventually, the prices rebounded as investors realized that they had overreacted.

Loewenstein, Weber, Hsee, and Welch (2001) proposed a model of risky choice whereby strong anticipatory emotions (e.g., fear and anxiety) felt at the moment of decision making play a role in the outcome. This risk-as-feelings hypothesis was tested in an experimental setting by Kuhnen and Knutson (2011); events associated with positive emotions were found to lead to riskier behavior, whereas those associated with negative emotions led to more risk-averse behavior.

Empirical studies have shown that traumatic events such as the 2008 financial crisis can affect willingness to take risk. The crisis provided a convenient setting for applying the riskas-feelings hypothesis. Using results of a survey of a large Italian bank's customers in 2007 and repeated in 2009, Guiso, Sapienza, and Zingales (2013) found that risk aversion increased after the 2008 financial crisis. They found support for a fear-based model that predicts that investors will sell stock after a sharp decline. Investors become less risk tolerant not simply because their wealth declined but also because of a traumatic event such as the sharp drop in stock prices. Availability bias impacted their risk tolerance.

In a study of German households, Necker and Ziegelmeyer (2014) found that those who attributed losses in wealth between 2007 and 2009 to the financial crisis experienced decreased risk tolerance, whereas those who did not attribute losses to the crisis saw no change in risk attitude. They attributed the change in risk tolerance to a psychological reaction to the financial crisis.

Risk tolerance has been found to be relatively stable over time, but individuals may exhibit time-varying risk aversion in the short run. Guillemette and Finke (2014) found that although risk tolerance scores were relatively stable in the long run, they were strongly correlated with recent stock market movements in the short run. Risk tolerance increased as stock market valuations increased and decreased during market downturns. Investors' appetites for risk tended to change in reaction to market returns.

Studies have shown that risk tolerance tends to increase when market returns increase, and decrease when market returns decrease (Yao \& Curl, 2011; Yao, Hanna, \& Lindamood, 2004). This tendency can be explained by availability bias or recency effect, a phenomenon whereby most recent events have the most impact on perceptions. Unfortunately, if investors act accordingly, they may undermine their returns by buying after a gain (when prices are high) and selling after a loss (when prices are low).

The recency effect is of special concern for young investors because younger individuals were found to be more sensitive to recent returns than older individuals (Malmendier \& Nagel, 2011). Some financial advisors have expressed concern that young investors hold portfolios that are too conservative, selecting safe investments over equities (Dagher, 2011; Light, Pilon, \& Silver-Greenbert, 2011; Yousuf, Wang, \& Derousseau, 2011). The experience of the depressed job market and decline in stock prices during the financial crisis may explain their reluctance to take risk. Regrettably, inadequate retirement funds are a likely result of this low risk tolerance. 
Recent research links behavioral finance constructs to risk tolerance. Griesdorn, Lown, DeVaney, Cho, and Evans (2014) investigated how decision-making strategies suggested by the behavioral life cycle hypothesis are related to risk tolerance. They found a significant positive relationship between self-control and risk tolerance. Those who scored higher in self-control scored significantly higher in risk tolerance. They also found to a lesser extent that mental accounting and framing constructs were related to risk tolerance.

\section{Demographic and Socioeconomic Characteristics}

Many empirical studies have shown that demographic and socioeconomic characteristics impact risk tolerance, although the evidence is mixed in terms of the direction of the impact. A preponderance of research has provided evidence that risk tolerance increases with wealth (Griesdorn et al., 2014; Hartog, Ferrer-i-Carbonell, \& Jonker, 2002; Schooley \& Worden, 1996) and income (Gibson, Michayluk, \& Van de Venter, 2013; Hartog et al., 2002). Some evidence supported the belief that risk tolerance decreases with age (Gibson et al., 2013; Griesdorn et al., 2014; Hallahan, Faff, \& McKenzie, 2004; Yao \& Curl, 2011; Yao et al., 2004); other studies found the relationship with age to be nonlinear (Hallahan et al., 2004; Riley \& Chow, 1992). Being married has been shown to have a significant negative impact on risk tolerance (Hallahan et al., 2004; Yao et al., 2004), although McInish (1982) did not find a significant relationship. Number of dependents has also been shown to have a negative impact on risk tolerance (Hallahan et al., 2004).

Research has provided evidence that education has a positive effect on risk tolerance (Griesdorn et al., 2014; Hallahan et al., 2004; Hartog et al., 2002; Yao \& Curl, 2011; Yao et al., 2004). Those who consulted a financial advisor exhibited lower risk tolerance (Gibson et al., 2013). Self-employed workers have been shown to be more risk tolerant than those who work for others (Colombier, Boèmont, Loeac, \& Masclet, 2008; Hartog et al., 2002; Sung \& Hanna, 1996; Yao et al., 2004). A study of how personality characteristics influence decisions on entrepreneurial status in German households found that the probability of entry into selfemployment is higher for those with higher risk tolerance (Caliendo, Fossen, \& Kritikos, 2014). Interestingly, the probability of exiting from self-employment is higher for those with low or high risk tolerance but lower for those with medium risk tolerance. They also found evidence that those who are more risk tolerant are more likely to be self-employed.
Conversely, Halek and Eisenhauer (2001) found evidence that the self-employed are more averse to downside risk than those employed by others. The inclusion of socioeconomic factors in an examination of risk tolerance is supported by these many and varied results.

The literature supports the notion that investors may not always behave rationally. They may overreact to bad news and behave in a more risk-averse manner when they experience negative emotions. Investors' reactions to a decrease in stock prices caused by a traumatic event such as the financial crisis can be much more emotional than to a gradual decrease in stock prices. Italian investors became less risk tolerant after the 2008 financial crisis. German households who attributed losses in wealth to the financial crisis experienced decreased risk tolerance. Risk tolerance has also been linked to socioeconomic and demographic characteristics such as the use of a financial advisor, education level, stage of life cycle (incorporating age, marital status, and children), employment status, income, and wealth.

The objective of this study was to examine how changes in U.S. households' risk tolerance (realized and perceived) is related to the 2008 financial crisis. Contrary to popular belief, not everyone became less risk tolerant as a result of the crisis. Univariate analysis tested the hypotheses that a household became more risk tolerant when its wealth increased after the crisis and became less risk tolerant when its wealth decreased after the crisis. Regression analysis tested the hypothesis that realized risk tolerance increased for those who perceive they became more risk tolerant and decreased for those who perceive they became less risk tolerant.

\section{Methods}

\section{Data and Sample}

The data for this study were from the 2007-2009 SCF panel. The SCF is a triennial interview survey of U.S. households sponsored by the Federal Reserve Board of Governors (FRB). The purpose of the SCF is to provide a comprehensive view of the financial behavior of a cross section of U.S. households. Information is gathered on assets and liabilities of the household as well as demographic and socioeconomic characteristics such as age, income, education, and makeup of the household unit. Attitudes toward risk taking are also surveyed. Because of the severity of the financial crisis and recession, in 2009, the FRB implemented a follow-up survey of households that had participated in the 2007 triennial 
SCF. The result was a panel database of information from the pairs of interviews that allowed for comparison between 2007 and 2009.

About $89 \%(3,862)$ of the eligible households completed the panel interview in 2009. To protect the privacy of several wealthy households, the public dataset was reduced to 3,857 . Furthermore, because of extreme values that indicated data error, one observation was eliminated from this analysis, reducing the sample size to 3,856 households. The panel data are available at the Federal Reserve website (FRB, 2009), and the surveys are described by Bricker, Bucks, Kennickell, Mach, and Moore (2011) and Kennickell (2011).

The 2007 SCF was conducted from May through December, with a few interviews in early 2008. During that time, it was obvious that the economy was slowing, even though the National Bureau of Economic Research (NBER) declared that the recession began in December 2007. The 2009 reinterview was conducted from July through December, with a few completed in early 2010. Although the economic recovery was not particularly strong, according to the NBER, June 2009 was the official ending of the recession (NBER, 2010).

\section{Variables}

The conventional definition of financial risk is uncertainty in returns. Because equity securities historically have exhibited the highest standard deviation of returns, investors' risk-taking behavior - their realized risk tolerance-was measured by the percentage of financial assets held in equity securities. Financial assets included transaction accounts, certificates of deposits, savings and other bonds, stock, pooled investment funds, retirement accounts, the cash value of life insurance, and other managed accounts such as trusts or annuities. Equity securities included stock held directly or indirectly through mutual funds and trusts. If a fund was reported as diversified, the SCF coding was employed to determine the value ascribed to equity holdings.

A household's perceived risk tolerance was measured by a response to a survey question. For each year, respondents were asked to identify their risk tolerance by selecting which one of the following statements reflects the amount of risk they were willing to take when saving or making investments:

- Take substantial financial risks expecting to earn substantial returns
- Take above-average financial risks expecting to earn above-average returns

- Take average financial risks expecting to earn average returns

- Not willing to take any financial risks

Respondents who selected the "substantial" statement were viewed to be the most risk tolerant (least averse) and those who selected the "not willing" statement were considered to be the least risk tolerant (most averse).

A comparison of the responses in the two interviews provided a measure of change in perceived risk tolerance after the financial crisis. A household who indicated a lower risktaking category in 2009, as compared to the 2007 choice, was deemed to perceive a lower risk tolerance level (more risk aversion). Conversely, one who indicated a higher risktaking category was deemed to perceive a higher risk tolerance (less risk aversion).

\section{Analysis}

This study's investigation of changes in risk tolerance used both univariate and multivariate analyses. Univariate analysis examined the relationship between wealth changes and changes in risk tolerance - both perceived and realized through changes in portfolio composition. The SCF use of a dual-frame sampling design that oversamples the wealthy required that an analysis weight be employed so that the distributions were representative of the populations of U.S. households. Because previous studies showed that wealth is significantly related to risk tolerance, changes in perceived risk tolerance were examined separately for households who experienced a decrease in wealth and those whose wealth increased. Also, changes in perceived risk tolerance and portfolio risk were examined to determine whether those who perceived that their risk tolerance had changed adjusted their portfolio risk (realized risk tolerance) accordingly. The analysis was extended further to determine if the results depended on whether wealth had increased or decreased.

Multivariate analysis was then used to examine factors that impacted the direction and magnitude of the change in the riskiness of a household's financial portfolio (realized risk tolerance) between the time of the 2007 and 2009 surveys. The dependent variable "PortRisk07-09" measured the difference in the percentage of financial assets held in stock: 2007 minus 2009. The larger the PortRisk07-09, the greater 
TABLE 1. Change in Asset Allocation-Percentage of Financial Assets Held in Stock 2007 Versus 2009

\begin{tabular}{lcc}
\hline $\begin{array}{l}\text { Change in Percentage Held } \\
\text { "PortRisk07-09" }\end{array}$ & Distribution of Households (\%) & Median Change 2007-2009 (\%) \\
\hline Decline $2007 \%>2009 \%$ & 35.3 & 21.1 \\
No change $2007 \%=2009 \%$ & 32.0 & 0.0 \\
Increase $2007 \%<2009 \%$ & 32.7 & -19.8 \\
\hline
\end{tabular}

Note. $n=3,621$; excludes 235 households that had no financial assets in 2007 and/or 2009 .

was the reduction in the percentage of financial assets held as stock. A negative difference indicates that the percentage of financial assets held in stock was greater in 2009 than it was in 2007. Variables for demographic and socioeconomic factors that have been shown in the literature to impact risk tolerance were included as explanatory variables. These include the use of a financial advisor, education level, stage of life cycle (incorporating age, marital status, and children), employment status, income, and wealth.

\section{Results}

\section{Descriptive Statistics}

Table 1 provides the distribution of households whose portfolio risk declined, increased, or saw no change between 2007 and 2009. Interestingly, the distribution is fairly even. As shown in Table 1,35.3\% of households decreased the percentage of stock held in their portfolios, whereas $32.7 \%$ increased the percentage of stock and $32 \%$ had no change. The median decline was $21.1 \%$, whereas the median increase was $19.8 \%$.

The distribution of households' perceived financial risk tolerance in 2007 versus 2009 , as measured by these responses, is presented in Table 2. In the aggregate, households appeared to perceive less risk tolerance in 2009 as compared to 2007. Six percent fewer households in 2009 reported that they were willing to take "above-average risk," as compared to 2007. And, 6\% more households in 2009 reported that they would not tolerate any risk in investments, as compared to 2007.

\section{Univariate Analyses}

As shown in Table 3, overall just over a quarter (25.9\%) of households reported less tolerance for risk after the financial crisis. Less than $16 \%$ of households reported a higher tolerance for risk after the financial crisis.

Table 3 also illustrates how the change in perceived risk tolerance was associated with the change in household wealth, defined as total assets minus total liabilities. The financial crisis had a varied impact, with $62.5 \%$ of households experiencing a decrease in wealth and $36.8 \%$ experiencing an increase in wealth. Only $0.7 \%$ experienced no change in wealth. Although the difference was not highly significant ( $p=.086$ ), the percentage reporting less risk tolerance was greater (at 27\%) for those households whose wealth decreased than for those whose wealth increased (at 24.4\%). A more significant difference $(p=.014)$ appeared for the percentage reporting more risk tolerance. Only $14.6 \%$ of households whose wealth decreased during the crisis perceived more tolerance for risk, compared to $18 \%$ of households whose wealth increased.

The financial portfolio composition for households revealed that the change in wealth and reported risk tolerance was associated with a change in investment behavior. Table 4 considers the composition of the portfolio of financial assets of households who experienced a change in wealth during the financial crisis-across the reported change in risk tolerance. As discussed earlier, a household's

TABLE 2. Distribution of Financial Risk Tolerance 2007 Versus 2009 "Willing to Take ..."

\begin{tabular}{lcccc}
\hline Survey Year & $\begin{array}{c}\text { Substantial Risk for } \\
\text { Substantial Returns (\%) }\end{array}$ & $\begin{array}{c}\text { Above-Average Risk for } \\
\text { Above-Average Returns (\%) }\end{array}$ & $\begin{array}{c}\text { Average Risk for } \\
\text { Average Returns (\%) }\end{array}$ & No Risk (\%) \\
\hline 2007 & 3.5 & 17.5 & 38.3 & 40.7 \\
2009 & 3.3 & 11.4 & 39.1 & 46.2 \\
\hline
\end{tabular}

Note. $n=3,856$ 
TABLE 3. Change in Financial Risk Tolerance by Change in Wealth: 2007 Versus 2009

\begin{tabular}{lcc}
\hline & \multicolumn{2}{c}{ Percentage Reporting a Change in Risk Tolerance } \\
\cline { 2 - 3 } Change in Wealth Between $\mathbf{2 0 0 7}$ and $\mathbf{2 0 0 9}$ & Less Risk Tolerance & More Risk Tolerance \\
\hline Decrease in wealth & $27.0 \%$ & $14.6 \%$ \\
Increase in wealth & $24.4 \%$ & $18.0 \%$ \\
$F$ & 2.96 & 6.30 \\
$p$ value & $.086^{\dagger}$ & $.014^{*}$ \\
Across all households & $25.9 \%$ & $15.8 \%$ \\
\hline
\end{tabular}

Note. $n=3,836$; excludes 20 households with no change in wealth.

${ }^{*} p<.05 .{ }^{\dagger} p<.10$.

risk-taking behavior, or realized risk tolerance, was measured by the percentage of financial assets held in equity securities. Furthermore, because of their low standard deviation of returns, liquid financial assets were defined as "risk-free," and the percentage of financial assets held in risk-free securities provided a measure of realized risk "intolerance."

More than $60 \%$ of households experienced a decrease in wealth during the time between the two surveys. Although a decline in stock valuation alone could cause the percentage of financial assets held in stock to decline, it is only for those households who reported less risk tolerance that the median percentage declined $(23.7 \%$ in 2007 to $14.8 \%$ in 2009). For those who reported a higher tolerance for risk, the median percentage of financial assets held in stock actually increased from $11.1 \%$ in 2007 to $17.1 \%$ in 2009 . On the other hand, the median percentage of risk-free assets increased (from $23.8 \%$ in 2007 to $33.2 \%$ in 2009) for those households who reported less risk tolerance.

TABLE 4. Portfolio Composition Across Change in Wealth and Risk Tolerance Percentage of Stock to Financial Assets and Risk-Free to Financial Assetsa 2007 Versus 2009 (Median Values)

Reported Change in Risk Tolerance

Change in Wealth Between 2007 and 2009

Less Risk Tolerance (\%)

More Risk Tolerance (\%)

Decrease in wealth

Stock/financial assets: 2007

23.7

14.8

23.8

33.2

Risk-free/financial assets: 2009

Increase in wealth

Stock/financial assets: 2007

Stock/financial assets: 2009

Risk-free/financial assets: 2007

Risk-free/financial assets: 2009
18.7

38.2

32.6
11.1

17.1

30.0

29.3

7.1

17.0

50.2

35.5

Note. $n=3,621$; excludes 235 households that had no financial assets in 2007 and/or 2009 .

aFinancial assets include transaction accounts, certificates of deposit, savings and other bonds, stock, pooled investment funds, retirement account holdings, the cash value of life insurance, and other managed accounts such as trusts and annuities. Stock includes equity shares held directly or indirectly through mutual funds and trusts, both in retirement and nonretirement accounts. Risk-free assets include transaction accounts, savings accounts, certificate of deposits, and the cashvalue of life insurance. 
About $37 \%$ of households experienced an increase in wealth during the time between the two surveys. For those who reported less risk tolerance in 2009, the median percentage of financial assets held in stock was relatively unchanged. However, for those who reported higher tolerance for risk, not only did the median percentage of financial assets held in stock increase from $7.1 \%$ in 2007 to $17.0 \%$ in 2009 , but the median percentage of financial assets held in liquid assets declined from $50.2 \%$ to $35.5 \%$.

These univariate analyses indicated that the financial crisis affected individuals' attitudes toward risk and the composition of their portfolio of financial assets in different ways depending on how their wealth changed.

\section{Multivariate Analyses}

Variable descriptions and statistics for the multivariate analysis are presented in Table 5 .

The change in perceived risk tolerance was included in the analysis by two indicator variables. The reduction in risk tolerance was captured by the variable "less risk tolerance," which took the value 1 when the household reported lower risk tolerance in 2009 as compared to 2007. An increase in risk tolerance was captured similarly by the variable "more risk tolerance." No change in perceived risk tolerance was included in the constant term. Financial sophistication and knowledge was measured by the variable "UseFinProfAdvisor," which indicated whether the household used advice from a financial professional to make decisions about savings and investments in 2007. A household's behavior was expected to be influenced during the financial crisis by an established relationship with an advisor.

The impact of the education level achieved by the household head was measured by the indicator variables high school, some college, and graduate degree, with college degree included in the constant term. The household's stage of life and family structure was measured by a modified version of the life cycle variable developed by Bojanic (1992). The life cycle variables captured the household head's age, the presence of a spouse or partner, and the presence of children. Employment status variables indicated whether the household head was self-employed or not employed, as compared to being employed by others. These socioeconomic factors were measured at the time of the 2009 reinterview because the analysis is interested in determining their impact on the change in the portfolio's composition between 2007 and 2009.
Only $2 \%$ of household heads exhibited a change in education level between 2007 and 2009. Although 20\% of households changed life cycle category during that period, the percentage for each category was minute because of the number possible. For employment status, $83 \%$ of household heads maintained the same employment status at the time of the surveys, with the remaining $17 \%$ again distributed in small percentages among the various possibilities.

Table 6 presents results of the linear regression analysis on the change in the ratio of stock to financial assets (PortRisk07-09).

The overall $F$ statistic for the regression had a significant $p$ value. Because there is evidence that a change in risk tolerance is related to wealth, the percentage change in the household's wealth during the financial crisis was included as a control variable. In addition, the percentage change in household income was held constant, so that the influence of education and employment status could be more clearly identified. Because what is of interest for this analysis is the change in the portfolio composition, the "starting value," that is, the percentage of financial assets held in stock in 2007 (PortRisk07), was included as an additional control variable. A PortRisk07-09 value of 5\% is more noteworthy if the percentage held in 2007 was $7 \%$ than if it was $30 \%$.

Those households who perceived a higher level of risk tolerance in 2009 had a significantly smaller reduction in the percentage of financial assets held as stock. In fact, they could have experienced an increase in this ratio. As expected, households who reported that they became more risk tolerant either increased the riskiness of their portfolios or reduced the equity holdings by a significantly smaller amount. However, the change in the portfolio composition was not significantly different for those households who perceived a lower level of risk tolerance. The other socioeconomic factors must have been the contributing factors to the change in their portfolios, not their perceived risk tolerance.

Whether the household used a financial professional to make savings and investment decisions at the beginning of the financial crisis was expected to have an impact on the change in the portfolio allocation, but it proved to be insignificant. The regression analysis was repeated using indicator variables that measured changes in the use of a financial 
TABLE 5. Variable Definitions and Descriptive Statistics ${ }^{a}$

\begin{tabular}{|c|c|c|}
\hline Dependent Variable & Definition & $M$ \\
\hline PortRisk07-09 & $\begin{aligned}= & \text { change in percentage of financial assets invested in stock } \\
& \text { between } 2007 \text { and } 2009 \text { (2007 minus 2009) }\end{aligned}$ & $2.28 \%$ \\
\hline Explanatory Variables & Definition & $\begin{array}{c}\text { Sample } \\
\text { Proportion }\end{array}$ \\
\hline \multicolumn{3}{|l|}{ Change in perceived risk tolerance } \\
\hline $\begin{array}{l}\text { Less risk tolerance (more risk } \\
\text { averse) }\end{array}$ & $\begin{array}{l}=1 \text { if the response to the risk tolerance question in } 2009 \text { indi- } \\
\text { cated less willingness to take financial risk than the response } \\
\text { in } 2007 ; 0 \text { otherwise }\end{array}$ & 0.27 \\
\hline $\begin{array}{l}\text { More risk tolerance (less risk } \\
\text { averse) }\end{array}$ & $\begin{array}{l}=1 \text { if the response to the risk tolerance question in } 2009 \\
\text { indicated more willingness to take financial risk than the } \\
\text { response in 2007; } 0 \text { otherwise }\end{array}$ & 0.15 \\
\hline $\begin{array}{l}\text { No change in risk tolerance/ } \\
\text { aversion }\end{array}$ & $\begin{array}{l}=0 \text { if the response to the risk tolerance question in } 2009 \\
\text { indicated the same willingness as reported in 2007; in the } \\
\text { constant }\end{array}$ & 0.58 \\
\hline UseFinProfAdvisor & $\begin{array}{l}=1 \text { if the household used a financial professional (lawyer, ac- } \\
\text { countant, banker, broker, financial planner) in } 2007 \text { to make } \\
\text { decisions about savings and investments; } 0 \text { otherwise }\end{array}$ & 0.50 \\
\hline Education level & Highest level of education earned by household head in 2009 & \\
\hline High school & $=1$ if high school diploma or less; 0 otherwise & 0.32 \\
\hline Some college & $=1$ if attended college, but a degree not earned; 0 otherwise & 0.16 \\
\hline College degree & $\begin{array}{l}=0 \text { if earned college degree, excludes trade school certificate; } \\
\text { in the constant }\end{array}$ & 0.29 \\
\hline Graduate degree & $=1$ if earned a graduate degree; 0 otherwise & 0.23 \\
\hline Life cycle & Family structure in 2009 & \\
\hline Single & $\begin{aligned}= & 1 \text { if single, age younger than } 55 \text { years, no children; } \\
& 0 \text { otherwise }\end{aligned}$ & 0.10 \\
\hline Couple & $\begin{array}{l}=1 \text { if married or with partner, age younger than } 55 \text { years, } \\
\text { no children; } 0 \text { otherwise }\end{array}$ & 0.08 \\
\hline Full Nest I & $\begin{array}{l}=1 \text { if married or with partner, age younger than } 40 \text { years, with } \\
\text { children; } 0 \text { otherwise }\end{array}$ & 0.08 \\
\hline Full Nest II & $\begin{array}{l}=0 \text { if married or with partner, age } 40 \text { years or older, with } \\
\text { children; in the constant }\end{array}$ & 0.23 \\
\hline Empty nest couple & $\begin{array}{l}=1 \text { if married or with partner, age } 55 \text { years or older, } \\
\text { no children; } 0 \text { otherwise }\end{array}$ & 0.26 \\
\hline Solitary survivor & $=1$ if single, age 55 years or older; 0 otherwise & 0.14 \\
\hline Single parent & $=1$ if single, any age, with children; 0 otherwise & 0.11 \\
\hline Employment status & Employment status of household head in 2009 & \\
\hline Employed by others & $=0$ if work for someone else; in the constant & 0.46 \\
\hline Self-employed & $=1$ if self-employed or partnership; 0 otherwise & 0.26 \\
\hline Not employed & $\begin{aligned}= & 1 \text { if unemployed, retired, or otherwise not in labor force; } \\
& 0 \text { otherwise }\end{aligned}$ & 0.28 \\
\hline
\end{tabular}


TABLE 5. Variable Definitions and Descriptive Statistics ${ }^{\text {a }}$ (Continued)

\begin{tabular}{|c|c|c|}
\hline Control Variables & Definition & Median \\
\hline Income percentage change & $\begin{array}{l}=\text { percentage change in reported household income between } \\
2007 \text { and 2009; income derived from all sources, including } \\
\text { withdrawals from IRAs and pension accounts }\end{array}$ & $-5.2 \%$ \\
\hline Wealth percentage change & $\begin{array}{l}=\text { percentage change in wealth calculated as the difference be- } \\
\text { tween } 2007 \text { and } 2009 \text { wealth, divided by the absolute value } \\
\text { of } 2007 \text { wealth. If a household had zero wealth in } 2007 \text {, a } \\
\text { value of } \$ 1 \text { is in the denominator. Wealth is measured by } \\
\text { household net worth - the total value of all real and financial } \\
\text { assets owned, including business equity, less the value of all } \\
\text { mortgage and consumer debt outstanding. }\end{array}$ & $-19.2 \%$ \\
\hline PortRisk07 & $=$ percentage of financial assets held in stock in 2007 & $28.7 \%$ \\
\hline
\end{tabular}

Note. $n=3,621$; excludes 235 households that had no financial assets in 2007 and/or 2009. IRAs $=$ individual retirement accounts.

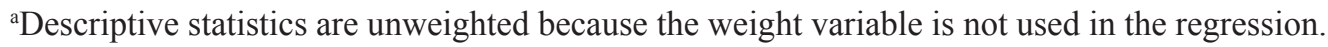

TABLE 6. Regression Analysis of Change in Ratio of Stock to Financial Assets: 2007 Minus 2009

\begin{tabular}{lccc}
\hline Explanatory variable & Estimated Coefficient & $\boldsymbol{F}$ Statistic & $\boldsymbol{p}$ Value \\
\hline Less risk tolerant (more risk averse) & 0.87 & 0.75 & .385 \\
More risk tolerant (less risk averse) & $-4.02^{* * *}$ & 10.82 & .001 \\
UseFinProfAdvisor & 0.40 & 0.21 & .649 \\
Education level & & & .000 \\
$\quad$ High school & $5.39^{* * *}$ & 18.24 & .020 \\
Some college & $3.57^{*}$ & 5.74 & .111 \\
Graduate degree & -2.30 & 2.65 & .028 \\
Life cycle & & & .957 \\
Single & $3.89^{*}$ & 4.95 & .118 \\
Couple & -0.11 & 0.01 & .860 \\
Full Nest I & 2.99 & 2.49 & .000 \\
Empty nest couple & 0.22 & 0.03 & .001 \\
Solitary survivor & $5.46^{* * *}$ & 12.33 & \\
Single parent & $5.17^{* * *}$ & 10.53 & .065 \\
Employment status & & & .000 \\
Self-employed & $2.12^{\dagger}$ & 3.44 & .107 \\
Not employed & $6.38^{* * *}$ & .858 \\
Income percentage change & 0.00 & 28.33 & .000 \\
Wealth percentage change & 0.00 & 2.60 & .000 \\
PortRisk07 & $0.54^{* * *}$ & 0.03 & \\
Constant & $-21.23^{* * *}$ & 984.31 & 159.95 \\
\hline
\end{tabular}

Note. $n=3,621$. Overall $F$ statistic $=72.9$ with $p$ value $=.000$. The adjusted $R^{2}$ ranged from 0.28 to 0.29 for the five separate imputation regressions.

${ }^{*} p<.05 .{ }^{* * *} p<.001 .{ }^{\dagger} p<.10$. 
professional. That is, additional variables were added to capture whether the household did not use a financial planner in 2007, but did in 2009, and vice versa. All variables had an insignificant impact on the dependent variable.

Further investigation showed that the use of a financial professional was highly correlated with the education status of the household head; the probability that a financial professional was used increased with education level. Thus, education level may have captured that effect. And, consistent with the results found in other studies (Griesdorn et al., 2014; Hallahan et al., 2004; Hartog et al., 2002; Yao \& Curl, 2011; Yao et al., 2004), education had the expected positive effect on risk tolerance in a portfolio.

Those households whose head had less education had a significantly larger reduction in the percentage of financial assets held in stock - compared to those with a college degree. Those with a graduate degree were not significantly different.

The stage of life and family structure proved to be somewhat significant. Although the presence of children or age of the household head was not significantly related to the change in asset allocation, being single was. Singles, with or without children, exhibited a significantly larger reduction in the percentage of financial assets in stock than those who were married or had a partner. This result runs counter to studies that have shown that being married negatively impacts risk tolerance (Hallahan et al., 2004; Yao et al., 2004). Perhaps this was because of the fact that single households do not have the possibility of a second source of savings and investment and so were more cautious in investment behavior. The regression analysis was conducted replacing the life cycle variables with variables measuring age of the household head and the presence of a partner or spouse. Similar to the life cycle results, age proved to be insignificant while being single - without a spouse or partner-had a significantly positive impact on the size of the reduction in the percentage of financial assets held in stock.

Households with self-employed or nonemployed heads in 2009 exhibited a significantly larger reduction in the percentage of financial assets held as stock-as compared to those employed by others. This employment status effect is in addition to the impact of an income differential and so is likely a psychological phenomenon. Although previous studies (Colombier et al., 2008; Hartog et al., 2002; Sung \& Hanna, 1996; Yao et al., 2004) found that the self-employed were more risk tolerant, those in this study became less risk tolerant after the financial crisis. The severity of the financial crisis and its devastating impact on the job market are the likely causes of this result.

\section{Discussion}

The question of how risk tolerance changed because of the 2008 financial crisis is not a simple one to answer. The study finds that the change in risk tolerance is related to the change in wealth experienced. A decrease in wealth is associated with a higher probability of reporting less risk tolerance, whereas an increase in wealth is associated with a higher probability of reporting more risk tolerance. In their study of the SCF panel data, Bricker, Bucks, Kennickell, Mach, and Moore (2012) investigated changes in household wealth and portfolio composition during the financial crisis. They suggested that a large majority of households passively accepted changes in their portfolio composition that were because of asset revaluation. However, this study found evidence that refutes the suggestion that households were passive. The way in which portfolio composition changed depended on whether wealth increased or decreased.

As also suggested by Bricker et al. (2012), declining stock values could explain why the percentage of financial assets held in liquid assets increased. However, it is only for those who reported less risk tolerance that the median percentage of risk-free assets increased. For those households who reported a higher tolerance for risk, the median value remained relatively unchanged. These results reveal a more than passive response to the financial crisis. It would be an odd coincidence if those who reported more risk tolerance actively managed their portfolios to increase risk, whereas those who reported less risk tolerance passively accepted the decreased risk in their portfolios resulting from changes in market valuations.

Those who perceive that they became less risk tolerant hold less risky financial portfolios than they did before the financial crisis. The danger in decreasing portfolio risk (holding less stock as a percentage of financial assets) after an event such as the 2008 financial crisis is that investors end up selling stock when prices are low. In doing so, they could fall further behind in achieving their financial goals. 


\section{Implications}

Single households, those households whose head has not earned a college degree or is either self-employed or not employed, may be especially vulnerable to decreasing their portfolio risk during major negative economic events. Financial advisors need to revisit with their clients about their risk tolerance, especially in light of the call for increased diligence because of the recent financial crisis. Although changes in demographic circumstances such as marriage or having children are overt signs that risk tolerance may have changed, market conditions can also change a client's tolerance for risk.

Commitment strategies can be used to influence households' saving and investment behavior. For example, Smith and Griesdorn (2014) found that the self-employed were more likely to make retirement contributions when they employed savings rules as a commitment strategy. Because those with more self-control have been shown to be more risk tolerant (Griesdorn et al., 2014), financial counselors may be able to help them become more comfortable taking risk by suggesting some commitment strategies. For example, they could suggest that their clients make a commitment to maintain a particular level of risk in their portfolios. As markets fluctuate, they may be less tempted to adjust their portfolio risk accordingly if they are committed to holding a portfolio with a particular amount of risk.

Clients need to be comfortable with the risk level they are taking, especially during economic downturns. Advisors can help investors overcome the recency effect so that market fluctuations do not cause them to change their allocations dramatically. They can assist clients in maintaining a sense of perspective so that they can overlook the latest news and keep a long-term focus.

Guillemette and Finke (2014) suggested that financial planners can be of great value by assisting their clients in developing a long-run strategy to deter them from selling low and buying high because their risk aversion varies in the short run.

\section{Limitations and Future Research}

Although the SCF risk aversion measure is widely used in risk tolerance literature, readers should interpret results with some caution. Some studies support the SCF risk measure as an effective proxy for risk tolerance. For example, Gilliam, Chatterjee, and Grable (2010) found that the SCF question indicated an individual's investment risk tolerance reasonably well. However, it has been suggested that this single-item measure may not capture risk tolerance as well as a multiquestion measure (Grable \& Lytton, 2001). Also, individuals may have limited ability to self-assess their risk tolerance. The SCF question may serve as a better measure of investment risk tolerance than financial risk tolerance. Even so, the measure does provide some information about risk tolerance. Future research could further study the response to the SCF question as well as explore better measures for assessing risk aversion.

\section{References}

Arrow, K. J. (1965). Aspects of the theory of risk-bearing. Yrjö Jahnsson Lectures. Helsinki, Finland: Yrjö Jahnsson Foundation.

Bojanic, D. (1992). A look at a modernized family life cycle and overseas travel. Journal of Travel and Tourism Marketing, 1(1), 61-78.

Bricker, J., Bucks, B., Kennickell, A., Mach, T., \& Moore, K. (2011). Surveying the aftermath of the storm: Changes in family finances from 2007 to 2009 (Finance and Economics Discussion Series 2011-17). Washington, DC: Board of Governors of the Federal Reserve System. Retrieved from http://www.federalreserve .gov/pubs/feds/2011/201117/201117pap.pdf

Bricker, J., Bucks, B., Kennickell, A., Mach, T., \& Moore, K. (2012). The financial crisis from the family's perspective: Evidence from the 2007-2009 SCF panel. The Journal of Consumer Affairs, 46(3), 537-555.

Caliendo, M., Fossen, F., \& Kritikos, A. S. (2014). Personality characteristics and the decisions to become and stay self-employed. Small Business Economics, 42(4), 787-814.

Colombier, N., Boèmont, L., Loheac, Y., \& Masclet, D. (2008). Risk aversion: An experiment with selfemployed workers and salaried workers. Applied Economics Letters, 15(10), 791-795.

Dagher, V. (2011, June 20). Come on Gen X, take some chances: Financial advisers worry that their younger clients are playing it too safe with their money. The Wall Street Journal, p. R3.

De Bondt, W., \& Thaler, R. (1985). Does the stock market overreact? The Journal of Finance, 40(3), 793-805.

Federal Reserve Board. (2009). Survey of consumer finances. Retrieved from http://www.federalreserve .gov/econresdata/scf/scrf_2009psurvey.htm 
Finke, M., \& Huston, S. (2003). The brighter side of financial risk: Financial risk tolerance and wealth. Journal of Family and Economic Issues, 24(3), 233-256.

Gibson, R., Michayluk, D., \& Van de Venter, G. (2013). Financial risk tolerance: An analysis of unexplored factors. Financial Services Review, 22(1), 23-50.

Gilliam, J., Chatterjee, S., \& Grable, J. (2010). Measuring the perception of financial risk tolerance: A tale of two measures. Journal of Financial Counseling and Planning, 21(2), 30-43.

Grable, J. E., \& Lytton, R. H. (2001). Assessing the concurrent validity of the SCF risk tolerance question. Financial Counseling and Planning, 12(2), 43-53.

Griesdorn, T., Lown, J., DeVaney, S., Cho, S., \& Evans, D. (2014). Association between behavioral life-cycle constructs and financial risk tolerance of low-to-moderateincome households. Journal of Financial Counseling and Planning, 25(1), 27-40.

Guillemette, M., \& Finke, M. (2014). Do large swings in equity values change risk tolerance? Journal of Financial Planning, 27(6), 44-50.

Guiso, L., Sapienza, P., \& Zingales, L. (2013). Time varying risk aversion (NBER Working Paper No. 19284). Cambridge, MA: National Bureau of Economic Research.

Halek, M., \& Eisenhauer, J. (2001). Demography of risk aversion. The Journal of Risk and Insurance, 68(1), $1-24$.

Hallahan, T. A., Faff, R. W., \& McKenzie, M. D. (2004). An empirical investigation of personal financial risk tolerance. Financial Services Review, 13(1), 57-78.

Hartog, J., Ferrer-i-Carbonell, A., \& Jonker, N. (2002). Linking measured risk aversion to individual characteristics. Kyklos, 55(1), 3-26.

Kennickell, A. (2011, August). Look again: Editing and imputation of SCF panel data. Paper presented at 2011 Joint Statistical Meeting, Miami, FL. Retrieved from http://www.federalreserve.gov/econresdata/scf/files/ ASA2011.1.pdf

Kuhnen, C. M., \& Knutson, B. (2011). The influence of affect on beliefs, preferences, and financial decisions. Journal of Financial and Quantitative Analysis, 46(3), 605-626.
Light, J., Pilon, M., \& Silver-Greenbert, J. (2011, November 5). The young and the riskless. The Wall Street Journal, p. B7.

Loewenstein, G. F., Weber, E. U., Hsee, C. K., \& Welch, N. N. (2001). Risk as feelings. Psychological Bulletin, 127(2), 267-286.

Malmendier, U., \& Nagel, S. (2011). Depression babies: Do macroeconomic experiences affect risk taking? The Quarterly Journal of Economics, 126(1), 373-416.

McInish, T. (1982). Individual investors and risk-taking. Journal of Economic Psychology, 2(2) 125-136.

National Bureau of Economic Research. (2010). US business cycle expansions and contractions. Retrieved from http://www.nber.org/cycles.html

Necker, S., \& Ziegelmeyer, M. (2014). Household risk taking after the financial crisis (MEA Discussion Paper Series 14279). Munich, Germany: Munich Center for the Economics of Aging at the Max Planck Institute for Social Law and Social Policy.

Riley, W., \& Chow, K. (1992). Asset allocation and individual risk aversion. Financial Analysts Journal, 48(6), 32-37.

Schooley, D., \& Worden, D. D. (1996). Risk aversion measures: Comparing attitudes and asset allocation. Financial Services Review, 5(2), 87-99.

Smith, H., \& Griesdorn, T. (2014). Do saving rules influence self-employed households' participation in tax-deferred retirement plans? Family \& Consumer Sciences Research Journal, 43(1), 47-60.

Sung, J., \& Hanna, S. (1996). Factors related to risk tolerance. Financial Counseling and Planning, 7(1), 11-19.

Tversky, A., \& Kahneman, D. (1973). Availability: A heuristic for judging frequency and probability. Cognitive Psychology, 5(2), 207-232.

Yao, R., \& Curl, A. (2011). Do market returns influence risk tolerance? Evidence from panel data. Journal of Family and Economic Issues, 32(3), 532-544.

Yao, R., Hanna, S., \& Lindamood, S. (2004). Changes in financial risk tolerance, 1983-2001. Financial Services Review, 13(4), 249-266.

Yousuf, H., Wang, P., \& Derousseau, R. (2011). The young and the riskless. Money, 40(1), 146-151. 
Reproduced with permission of the copyright owner. Further reproduction prohibited without permission. 